

\title{
Comparison of the distribution maps for drug addict hotspot in Selangor using different spatial analysis tools
}

\author{
Hasranizam Hashim ${ }^{1}$, Nor Aizam Adnan ${ }^{1,2}$, Syaza Fillza Shamsulkamar ${ }^{1}$, Chan Yuen Fook ${ }^{3}$, \\ Wan Mohd Naim Wan Mohd ${ }^{1}$ \\ ${ }^{1}$ Centre of Studies for Surveying Science \& Geomatics, Faculty of Architecture, Planning \& Surveying, \\ Universiti Teknologi MARA, UiTM Shah Alam \\ ${ }^{2}$ Applied Remote Sensing and Geospatial Research Group, \\ Faculty of Architecture, Planning \& Surveying, Universiti Teknologi MARA, UiTM Shah Alam \\ ${ }^{3}$ Faculty of Education, Universiti Teknologi MARA, UiTM Shah Alam \\ Correspondence: Nor Aizam Adnan (email: nor_aizam@uitm.edu.my)
}

Received: 16 September 2019; Accepted: 28 August 2020; Published: 28 August 2020

\begin{abstract}
The problem of drug addiction in Malaysia is worsening and causes harm to the well-being of the population of Malaysia. A report published in 2018 states that 133,684 or 0.4\% of the Malaysian population are drug addicts. Furthermore, $56 \%$ of all inmates in the federal prison are locked-up because of drug-related offences. This study aim is to identify the hotspots for drug addicts in Selangor, Malaysia. This study uses three geostatistical techniques, kernel density estimation (KDE), Getis-Ord Gi*, and IDW to map the hotspots for drug addicts. The National Anti-Drug Agency (NADA) provides the data for this study which consists of 2997 cases of drug addict under supervision (DAUS) in 2016. The data are analysed using ArcGIS Pro 2.4 software. The individual DUAS represents a point vector data format with WGS 1984 Web Mercator projection. Hotspot analysis is performed using kernel density estimation (KDE), Getis-Ord Gi* and IDW. The results show eight statistically significant hotspots for drug addicts in the subdistricts $(99 \%$ confidence level and p-value $<0.001)$. The locations with significant hotspots for drug addicts are Bandar Serendah, Pandamaran, Bandar Klang, Bandar Kajang, Dengkil, Bandar Ampang, Bandar Damansara, and Semenyih sub-districts. This study provides spatial information that helps law enforcement agencies identify drug hotspot areas and use this information to create and enhance a defensible safe neighbourhood. The outcome of this study facilitates law enforcement through better strategic planning for reducing drug addict hotspot areas.
\end{abstract}

Keywords: drug addicts, drug hotspots and mapping, geographical information system (GIS), Getis-ord $\mathrm{Gi}^{*}$, inverse distance weighted (IDW), kernel density estimation analysis (KDE) 
GEOGRAFIA Online ${ }^{\mathrm{TM}}$ Malaysian Journal of Society and Space 16 issue 3 (263-278)

(C) 2020, e-ISSN 2682-7727 https://doi.org/10.17576/geo-2020-1603-19

\section{Introduction}

In Malaysia, drug addiction results in negative social indicators that impact the well-being of families, communities, and the nation. One report states that 133,684 or $0.4 \%$ of the Malaysian population are drug addicts (Berita Harian, 2018). Furthermore, 73.4\% of the drug addicts are youth between the age of 19 to 39 years old, and $80.6 \%$ of them are Malays. The states with the highest number of drug addicts based on the ratio of the total population are Pahang, Kelantan, Terengganu, and Perlis.

This study investigates the early identification of high-risk locations for drug activity hotspots. Hotspot generally refers to an area with a concentration of an event and is frequently used in Geographical Information System (GIS). Chainey and Ratcliffe (2005) define hotspot as a geographical area with higher than average concentration, or a cluster, of an event. The hotspot in this study is an area with prevalent drug activities and often contains a large number of drug activities. Knowing the locations of drug hotspot is the first step in determining why these locations are afflicted with a persistent problem. Analysis and mapping of drug addict hotspots will give a geographical pattern for drug hotspots in a particular area. According to Jefferis (1999), point mapping is the most suitable method for depicting geographic patterns. Hotspot mapping is a common practice in the police force across the globe (Kalinic \& Krisp, 2018; Leigh et al., 2016; Gill et al., 2015; Chainey, 2013; Gorr \& Kurland, 2012; United Nation, 2018).

The history of drug addiction in Malaysia goes back to the early 19th century. The Chinese labourers brought with them the habit of sucking opium, the Indian labourers brought with them marijuana, and the Malays used cannabis as a cure for fatigue (Malaysia, AntiNarcotics Task Force, 1992). The National Anti-Drug Agency (NADA) identifies 178 locations as high-risk areas for drug use (Bernama, 2019). In 2018, the Director-General of NADA stated that there are 87 locations in Malaysia with a very high risk of drug addiction where over $70 \%$ of all drug cases occurred in these areas. Eighty-six zones are high-risk areas with between $0.5 \%$ to $30 \%$ drug cases, and five zones are moderately high-risk zone with less than $0.5 \%$ drug cases. NADA targeted for 33 of the 178 high-risk areas to be drug-free zones by the end of 2019 (Bernama, 2019). The identified high-risk areas are federal housing projects (PPRs), fishing villages, and the Federal Land Development Authority (FELDA) settlements. The National AntiDrug Agency (2017) reported that the states with the highest number of drug addicts are Pulau Pinang, Kelantan, Selangor, and Johor. The most common reason for drug abuse is peer influence.

According to the Malaysian Prison Department, 56\% of all prisoners are jailed because of drug-related offences. Furthermore, 1,252 schoolchildren, especially secondary school children between 16 and 17 years old, take drugs (Utusan Malaysia, 2017). Methamphetamines, particularly syabu and pil kuda, are the most frequently used drugs (61.9\%) (Astro Awani, 2019). These data indicate that drug addiction is a serious problem in Malaysia, and further investigation is necessary to identify the hotspot areas for drug addiction.

Chan \& Nor Aizam (2018) use geospatial analysis to identify the hotspot areas for drugs in Malaysia, and the result shows that among the hotspots for drug use are Klang, Damansara, Ampang Jaya, Kota Setar, Jitra and Georgetown. Investigation of hotspots for drug addicts using a GIS approach is still on-going. The present study performs an in-depth GIS analysis of hotspot areas for drug addiction using multi geospatial analysis tools. According to Fazillah et al. (2017), only a small number of studies combine GIS analysis with multivariate analysis method to investigate substance abuse. 
A drug is any chemical substance that affects the normal functioning of the body and brain (United Nations, 2007). A drug also refers to a substance which, when taken into the body, alter the body's function physically or psychologically. There are different kinds of drugs, for example, cannabis, cocaine, ecstasy, heroin, and many others. According to the Drug Dependants (Treatment and Rehabilitation) Act 1983 (Act 283), a drug addict is a person who uses any dangerous drug to experience a mental and, sometimes, physical state.

Kernel density estimation (KDE) is the most popular hotspot mapping technique and is often used by GIS analysts to analyse and display geographic concentrations of point events (Kalinic \& Krisp, 2018; Boba, 2016; Chainey, 2013; Gorr \& Kurland, 2012; Chainey \& Ratcliffe, 2005). Kernel estimation estimates how the density of an event changes spatially depending on a given point pattern. It creates a continuous surface of density values which, at a given location, reflects the concentration of points in the area surrounding that location. One of the main advantages of kernel estimation is that it can quickly turn an intricate concentration pattern of points into a smooth and easily understandable image.

The most recent method for producing a hotspot map is by using a GIS tool which calculates the Getis-Ord Gi* statistics (pronounced G-i-star) for each feature in the dataset. The results of this analysis are the p-value and z-score for each feature, where statistically significant hotspots typically have a high p-value and z-score. ESRI (2019) defines statistically significant hotspots as those with a high value surrounded by other parameters with equally high value. Inverse distance weighted (IDW) interpolation determines the cell values by using a linearly weighted combination of a set of sample points and is frequently used in GIS-related hotspot mapping. Therefore, this study aims to map the hotspots for drug addicts in Selangor through several geostatistical analyses. The present study uses three techniques to produce hotspot maps for drug addicts, kernel density estimation (KDE), Gi* statistics, and inverse distance weighted (IDW).

\section{Method and study area}

The study area is the state of Selangor, which is known as one of the hotspots for drug addicts in Malaysia. According to NADA, Selangor has the highest number of drug addicts, and there are 15 areas in Selangor with high drug risk. The primary objective of this study is to determine whether the geospatial techniques will identify the 15 locations as hotspot areas in Selangor. Three spatial analysis tools, Kernel Density Estimation (KDE), Getis-Ord Gi*, and Inverse Distance Weighted (IDW), are used to generate the map for hotspots for drug addicts.

This study uses the data for individual drug addict under supervision (DAUS) for 2016 and 2017 provided by the National Anti-Drug Agency (NADA). Figure 1 shows all the individual point data for the location of the drug addicts in the 227 sub-districts (mukim) in Selangor. The data is processed using the ArcGIS Pro 2.4 software with WGS 1984 Web Mercator projection. NADA recorded 2997 DAUS cases in 2016 and 832 cases in 2017 (Figure 2). Petaling district has the highest number of drug addicts followed by Hulu Langat (Ampang) and Klang. 


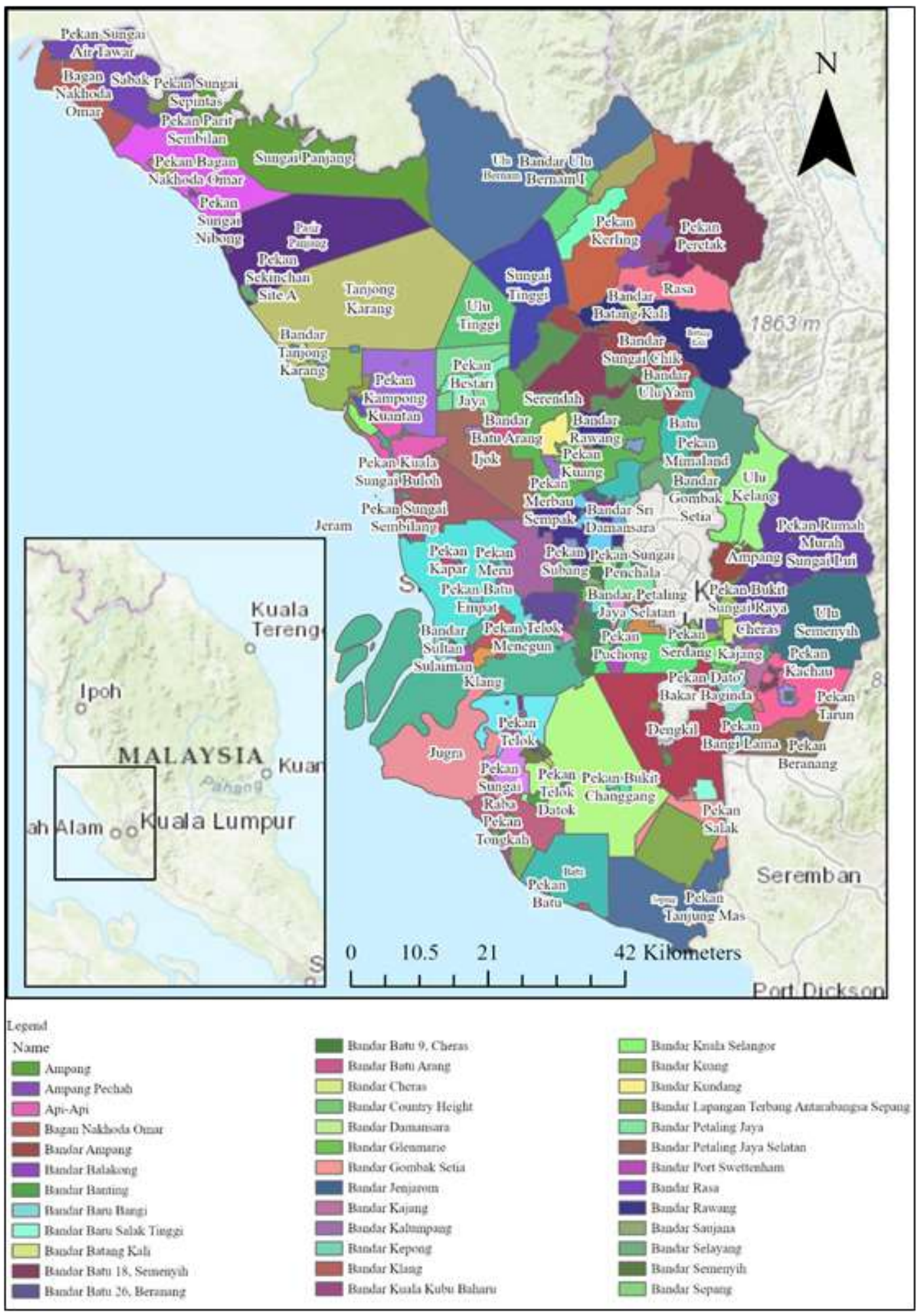

Figure 1. Map of the study area 


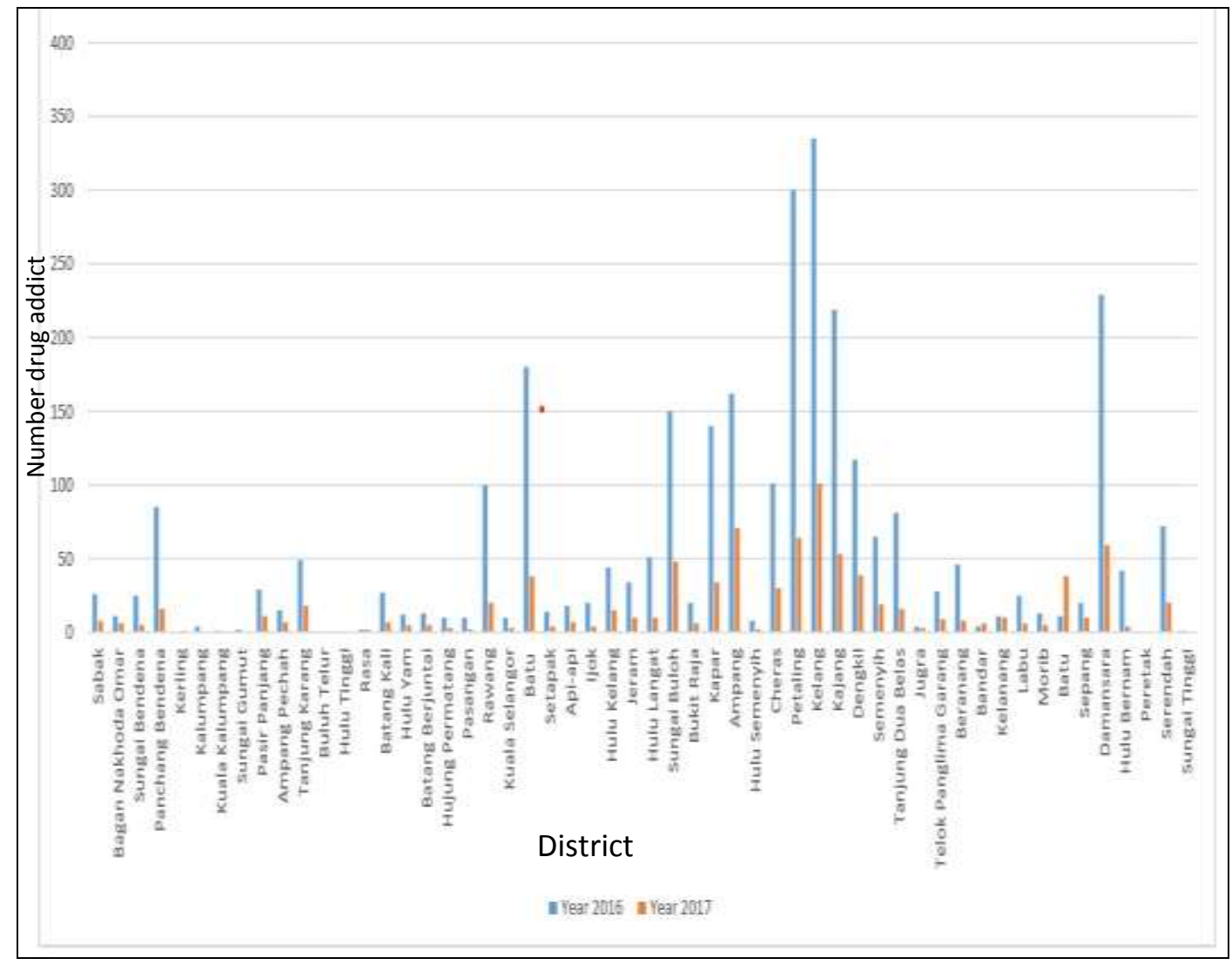

Figure 2. Number of drug addicts by district for 2016 and 2017

\section{Kernel Density Estimation (KDE) mapping technique}

Kernel density estimation (KDE) analysis is used to understand the identification of hotspot for drug addicts. This study adopts the methodology that underlies the crime pattern theory proposed by Brantingham \& Brantingham (1984) and the KDE technique introduced by Chainey et al. (2002) and Eck et al. (2005).

Figure 3 shows the four stages in the process for creating hotspot maps as proposed by Chainey et al. (2002) and Eck et al. (2005). The four stages are geocoding of the incident points, creating the grid, defining the bandwidth, and assigning values to the squares. Most GIS software, including ArcGIS, MapInfo, QGIS and CrimeStat, provides quartic kernel density estimation that requires two critical parameters, namely the grid cell and bandwidth. Bandwidth is the lead parameter which determines the density or volume of point pattern distribution that produces a smooth continuous surface to represent the hotspots throughout the study area.

The first stage is the process of geocoding the location of each DAUS, which is the $\mathrm{x}, \mathrm{y}$ coordinate in the GIS environment before performing the hotspot analysis. In the processing stage, a grid is laid over the area of the drug addict points. The grid size is known as the output of grid size. In this study, the grid size is in metre. The 447-metre output cell size is selected due to its suitability for the size of the study area. A cell with 447 output grid size represents a $447 \mathrm{~m}$ $\mathrm{x} 447 \mathrm{~m}$ square on the ground. The selected grid size will determine the resolution of the map and the processing time. A cell with a large grid size produces a very blocky map. Although a small grid will generate a map with a very high resolution, the processing time will also increase 
significantly. Furthermore, a 477-meter raster size is selected because this distance covers the average neighbourhood proposed by PLANMalaysia (2010). Both grids are technically correct but will produce a map with different resolutions.



Source: ESRI UK, 2016

Figure 3. Process of kernel density estimation (KDE) technique

The third stage is defining the value of bandwidth, which is essential for search radius or distance. The process looks at each grid cell and counts the crimes that occur in this bandwidth distance. The search radius is 1900 meters. The unit area is in square kilometre. The points closer to the centre of the cell are more influential than the points further away. The accumulated value gives the density value for the grid cell. Finally, each grid square is processed and assigned a related value for the number of points in or near the grid. The assignment of density values to each cell produces a continuous surface density map, which is the density or hotspots map.

The calculation of kernel density for the points uses a quartic kernel (Silverman, 1986) by using formula (1) in the ArcGIS kernel density tool (ESRI, 2019).

$$
\begin{gathered}
\text { Density }=\frac{1}{\left({\text { radius })^{2}}_{i=1}^{n}\right.} \sum_{i=1}^{n}\left[\frac{3}{\pi} \cdot \text { pop }_{i}\left(1-\left(\frac{\text { dist }_{i}}{\text { radius }}\right)^{2}\right)^{2}\right] \\
\text { For } \text { dist }_{i}<\text { radius }
\end{gathered}
$$

where

$i=1 \ldots, \mathrm{n}$ are the input points. The points are included in the sum only if they are within the radius distance of the $(\mathrm{x}, \mathrm{y})$ location. 
pop $_{i}$ is the population field value of point I, which is an optional parameter. dist $_{i}$ is the distance between point $\mathrm{i}$ and the $(\mathrm{x}, \mathrm{y})$ location.

The calculated density is multiplied by the number of points. The calculated density is in a raster format and is used to replace the centre value of every cell. Figure 4 shows the workflow process for the KDE analysis in this study, which is the standard workflow for KDE tool analysis using model builder ArcGIS Pro 2.4 software.

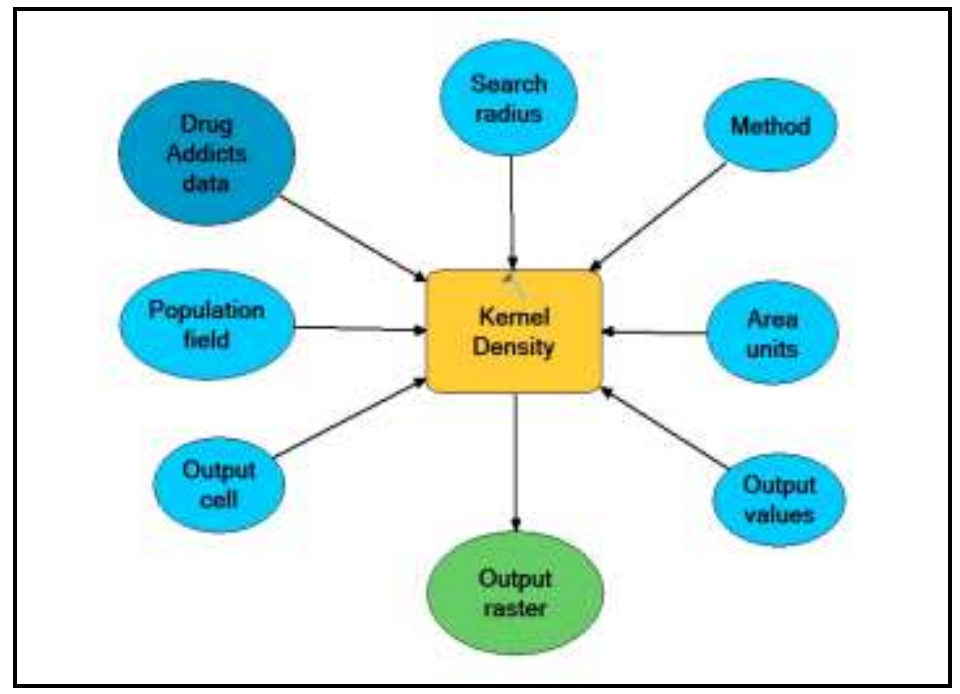

Figure 4. The workflow for kernel density estimation (KDE) technique

\section{Getis-Ord Gi* and IDW hotspot mapping techniques}

Figure 5 shows the workflow for Getis-Ord Gi* and IDW analysis. The workflow for analysis with Getis-Ord Gi* and IDW tools is for producing a hotspot map using a model builder tool in ArcGIS Pro 2.4 software involves seven steps.



Figure 5. Workflow for Getis-Ord Gi* and IDW techniques for producing drug addict hotspot map 
GEOGRAFIA Online ${ }^{\mathrm{TM}}$ Malaysian Journal of Society and Space 16 issue 3 (263-278)

(C) 2020, e-ISSN 2682-7727 https://doi.org/10.17576/geo-2020-1603-19

\section{Results and discussion}

Drug addict distribution area by sub-district

The distribution of drug addicts is by the total number of DAUS within the boundaries of the 227 sub-districts. Figure 6 shows the five classifications (Class 1 to Class 5) of drug addict distribution based on Natural Breaks (Jenks). Class 1 has 0-2 drug addicts, Class 2 has 4-10 drug addicts, Class 3 has 10-20 drug addicts, Class 4 has 20-30 drug addicts, and Class 5 has 30-70 drug addicts. Two of the 227 sub-districts, Bandar Ampang and Klang, have a very high number of DAUS (between 33 and 71). Bandar Petaling Jaya, Kapar, Dengkil and Bandar Kajang are in Class 4 and have between 20 to 32 drug addicts. Nine sub-districts are in Class 3, namely, Ulu Kelang, Shah Alam, Bandar Serendah, Bandar Damansara, Tanjung Karang, Bandar Sunway, Pandamaran, Cheras and North Petaling. These areas have between 10 and 19 DAUS. The remaining sub-districts are in Class 1 or Class 2.

The areas with the smallest number of drug addicts are Pekan Jenjarom, Sg. Manggis and Morib. The result of the analysis shows that the areas with the highest number of drug addicts are in the Klang Valley, which is the most developed urban area. The locations with a very small or small number of drug addicts are rural and intra-urban areas with moderate urbanisation. Bandar Ampang, Klang, Bandar Petaling Jaya, Kapar, Dengkil, and Bandar Kajang are areas with a high or very high number of drug addicts. These sub-districts are rapidly urbanising areas and have the highest population in the Klang Valley, indicating that drug addicts are often from urban areas.

According to the National Anti-Drug Agency (2017), 15 areas in Selangor are high-risk drug crime areas. Table 1 shows a comparison of the findings by the National Anti-Drug Agency with the result of this study. The result from geospatial classification indicates that there are only six hotspot drug areas. Interestingly, Kapar and Dengkil are not included as hotspots area by NADA.

Table 1. Comparison of hotspots for drug addicts identified by NADA and Geospatial methods (Natural Breaks (Jenks)

\begin{tabular}{|c|c|c|c|c|c|}
\hline Number & \multicolumn{3}{|c|}{ National Anti-Drug Agency (NADA) } & Number & Geospatial analysis \\
\hline 1 & Petaling Jaya & 9 & Sungai Besar & 1 & Bandar Ampang \\
\hline 2 & Serdang & 10 & Kajang & 2 & Klang and Pandamaran \\
\hline 3 & Bandar Ampang & 11 & Semenyih & 3 & Bandar Petaling Jaya \\
\hline 4 & Hulu Kelang & 12 & Batu 9 Cheras & 4 & Kapar \\
\hline 5 & Pandan Indah & 13 & Bangi & 5 & Dengkil \\
\hline 6 & Bandar Gombak & 14 & Pandamaran & 6 & Bandar Kajang \\
\hline 7 & Selayang & 15 & Bandar Klang & & \\
\hline 8 & Rawang & & & & \\
\hline
\end{tabular}




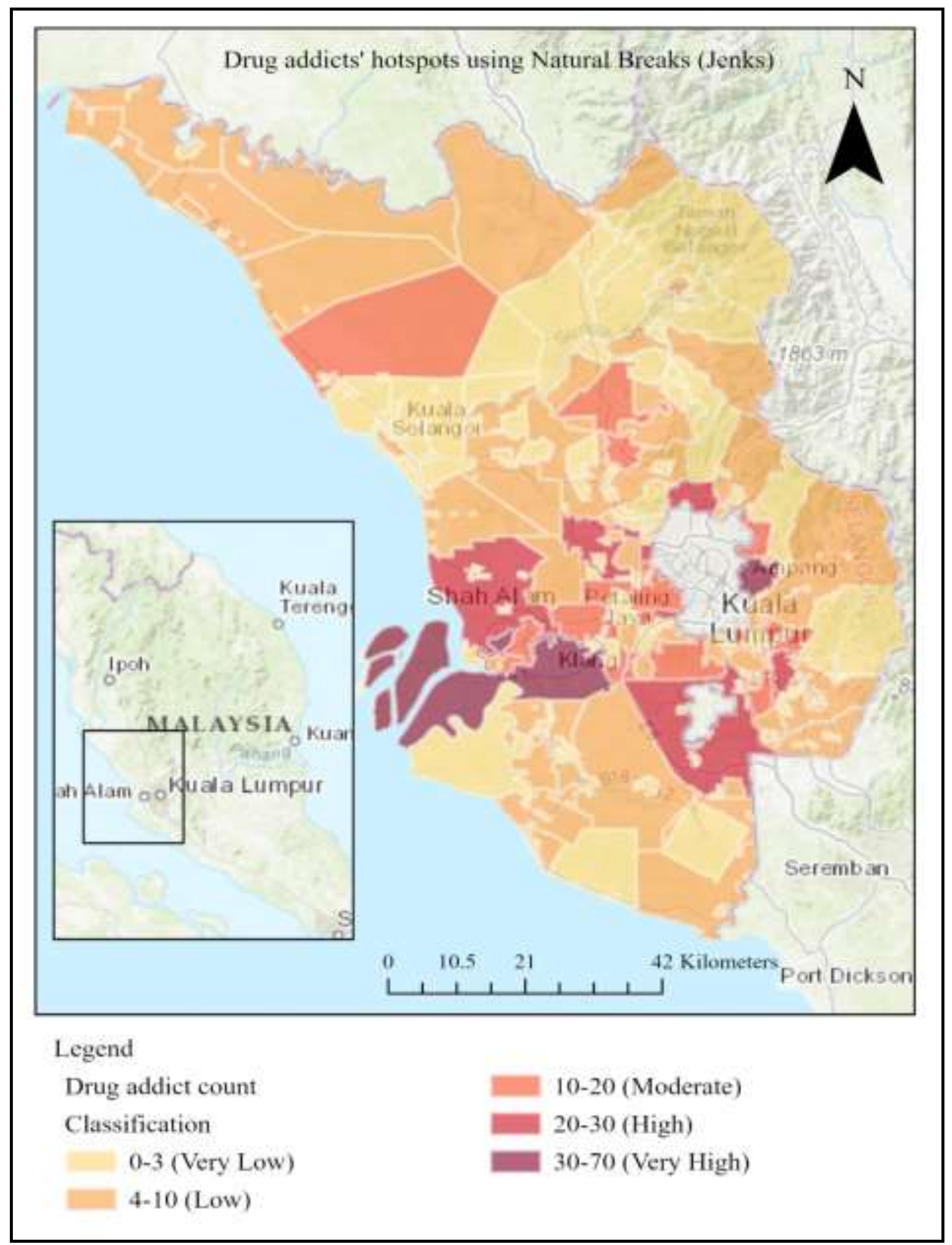

Figure 6. Drug addicts distribution areas by sub-district

\section{Hotspot for drug addict using Kernel Density Estimation (KDE)}

The hotspot maps depict the data surface in this study. The search radius bandwidth is 1900 metres with a 477-meter grid cell size. Figure 7 shows that as the search radius increases to 1900 meters, the hotspot becomes more generalised. The kernel density function is ideal for identifying areas with a large number of drug addicts and forgiving a broad idea of the pattern of drug addiction based on the raster format. 
The 477-meter raster size is selected because this distance covers the average of a standard neighbourhood and because the raster size shows variation at the regional level as described by PLANMalaysia (2010). The 1900-metre bandwidth is the expected mean distance when using the Average Nearest Neighbour (ANN) tool to determine whether the drug addict distribution point is a cluster, random, or dispersed.

The result of KDE analysis shows that there are three areas with a high number of drug addicts, namely Petaling Jaya, Klang-Pandamaran and Bandar Ampang. These areas have the highest concentration of drug addicts or are hotspots areas (Figure 6). Bandar Klang, Bandar Ulu Kelang, Bandar Selayang, Pekan Puchong, and Bandar Damansara have a modest number of drug addicts based on the raster format. The remaining areas are cold spots.



Figure 7. Hotspots for drug addicts identified by Kernel Density Estimation (KDE) 
Table 2 shows a comparison of the hotspots for drug addicts identified by the National Anti-Drug Agency (2017) with the hotspots identified using classification with Kernel Density Estimation (KDE). The result of the KDE analysis shows that there are only three hotspots for addicts. Interestingly, all hotspot areas identified by NADA are in high-density areas such as the city centres or towns identified in the KDE analysis.

Table 2. A comparison of the hotspots for drug addicts identified by NADA and Kernel Density Estimation (KDE) method

\begin{tabular}{ll|ll}
\hline Number & National Anti-Drug Agency (NADA) & Number & $\begin{array}{l}\text { Kernel } \\
\text { Estimation (KDE) }\end{array}$ \\
\hline 1 & Petaling Jaya & 1 & Bandar Ampang \\
2 & Serdang & 2 & Bandar Petaling Jaya \\
3 & Bandar Ampang & 3 & Klang and Pandamaran \\
4 & Hulu Kelang & & \\
5 & Pandan Indah & & \\
6 & Bandar Gombak & & \\
7 & Selayang & \\
8 & Rawang & \\
9 & Sungai Besar & & \\
10 & Kajang & & \\
11 & Semenyih & & \\
12 & Batu 9 Cheras & & \\
13 & Bangi & & \\
14 & Pandamaran & & \\
15 & Bandar Klang & & \\
\hline
\end{tabular}

Hotspot for drug addicts using Getis-Ord Gi* and IDW (Hot Spot analysis)

The Getis-Ord Gi* and IDW methods are used to determine the hotspots for drug addicts based on the sub-district boundary for the statistically significant hotspot. Figure 8 shows that several cities are statistically significant hotspots $(99 \%$ confidence with p-value $<0.001)$. Eight areas, namely Bandar Serendah, Klang-Pandamaran, Bandar Klang, Bandar Kajang, Dengkil, Bandar Ampang, Bandar Damansara, and Semenyih, are the hotspots for a large number of drug addicts. Bandar Serendah is a large area surrounded by the FELDA settlement and is the most significant hotspot, followed by Pandamaran which is surrounded by the People's Housing Program. Table 3 shows that the macro study area is a statistically significant hotspot for drug addicts. 
GEOGRAFIA Online ${ }^{\mathrm{TM}}$ Malaysian Journal of Society and Space 16 issue 3 (263-278)

(C) 2020, e-ISSN 2682-7727 https://doi.org/10.17576/geo-2020-1603-19

Table 3. A comparison of the hotspot for drug addicts identified by NADA and the Getis-Ord Gi* and IDW methods

\begin{tabular}{ll|ll}
\hline Number & National Anti-Drug Agency (NADA) & Number & $\begin{array}{l}\text { Getis-Ord Gi* and } \\
\text { IDW }\end{array}$ \\
\hline 1 & Petaling Jaya & 1 & Bandar Serendah \\
2 & Serdang & 2 & Klang and Pandamaran \\
3 & Bandar Ampang & 3 & Bandar Klang \\
4 & Hulu Kelang & 4 & Bandar Kajang \\
5 & Pandan Indah & 5 & Dengkil \\
6 & Bandar Gombak & 6 & Bandar Ampang \\
7 & Selayang & 7 & Bandar Damansara \\
8 & Rawang & 8 & Semenyih \\
9 & Sungai Besar & & \\
10 & Kajang & & \\
11 & Semenyih & & \\
12 & Batu 9 Cheras & & \\
13 & Bangi & & \\
14 & Pandamaran & & \\
15 & Bandar Klang & & \\
\hline
\end{tabular}




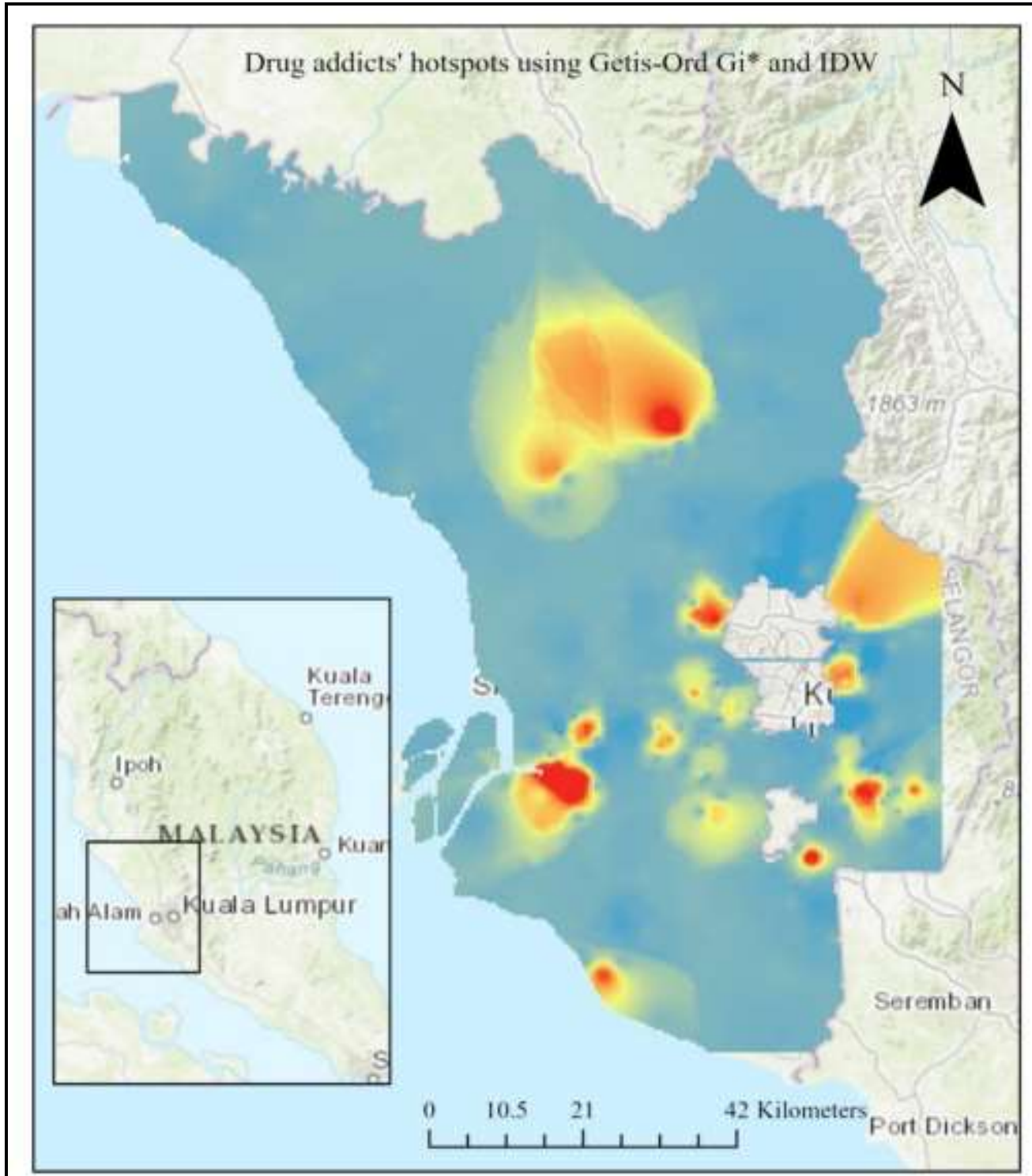

Legend

Drug addict's hotspots surface

Value

High : 7

Low : 0

Figure 8. Hotspots for drug addicts identified using Getis-Ord Gi* and IDW (Hot Spot analysis)

Table 4 shows a comparison of the hotspot areas identified using three different methods (Natural Breaks (Jenks), KDE, and Getis-Ord Gi*). When using the GIS approach, the results for analysis with Getis-Ord Gi * and IDW tools show a higher number of hotspots areas. The GetisOrd Gi * and IDW tools identify eight statistically significant hotspot areas $(99 \%$ confidence level with p-value <0.001). 
GEOGRAFIA Online ${ }^{\mathrm{TM}}$ Malaysian Journal of Society and Space 16 issue 3 (263-278)

(C) 2020, e-ISSN 2682-7727 https://doi.org/10.17576/geo-2020-1603-19

Table 4. A comparison of hotspots for drug addicts identified by KDE and Getis-Ord Gi* and IDW methods

\begin{tabular}{|c|c|c|c|c|c|}
\hline Ranking & $\begin{array}{l}\text { Natural } \\
\text { (Jenks) }\end{array}$ & Ranking & $\begin{array}{l}\text { Kernel Density } \\
\text { Estimation (KDE) }\end{array}$ & Ranking & Getis-Ord Gi* \& IDW \\
\hline 1 & Bandar Ampang & 1 & Bandar Ampang & 1 & Bandar Serendah \\
\hline 2 & \multicolumn{4}{|l|}{ Pandamaran } & Klang and Pandamaran \\
\hline 3 & $\begin{array}{l}\text { Bandar Petaling } \\
\text { Jaya }\end{array}$ & 3 & $\begin{array}{l}\text { Klang } \\
\text { Pandamaran }\end{array}$ & 3 & Bandar Klang \\
\hline 4 & Kapar & & & 4 & Bandar Kajang \\
\hline 5 & Dengkil & & & 5 & Dengkil \\
\hline \multirow[t]{3}{*}{6} & Bandar Kajang & & & 6 & Bandar Ampang \\
\hline & & & & 7 & Bandar Damansara \\
\hline & & & & 8 & Semenyih \\
\hline
\end{tabular}

\section{Conclusion}

The three geospatial analysis tools identify different hotspot areas. The results show that only six city areas, namely Bandar Ampang, Klang-Pandamaran, Bandar Petaling Jaya, Kapar, Dengkil, and Bandar Kajang have a high number of drug addicts in the Natural Breaks (Jenks) classification. The result for KDE analysis shows that the search radius is a critical parameter, where a bigger search radius produces a more generalised hotspot. The KDF method identifies three areas, namely the sub-district of Petaling Jaya, Klang-Pandamaran, and Bandar Ampang. On the contrary, the results of Getis-Ord Gi* and IDW identify eight cities as having a high number of hotspots for drug addicts, namely Bandar Serendah, Klang-Pandamaran, Bandar Klang, Bandar Kajang, Dengkil, Bandar Ampang, Bandar Damansara and Semenyih. These hotspot methods are popular and reliable tools in many point data hotspots analysis. Most of the hotspots areas are close to the FELDA settlement and People's Housing Program. The analyses with Getis-Ord Gi * and IDW tools produce the highest number of statistically significant hotspot areas for drug addicts (18 hotspot areas) in comparison to the 15 hotspot areas listed by NADA (99\% confidence with p-value <0.001).

The Malaysia National Anti-Drug Agency (NADA) has identified 15 city areas as a highrisk area for drug addicts in Selangor. However, this study identifies only eight hotspots for drug addicts. This research has shown that GIS spatial analysis can identify drug addicts in the hotspot for drug addicts in areas with low-density and high-density population. GIS is a reliable spatial method which can help policymakers implement better countermeasures to reduce the number of new drug addicts or relapse drug addiction.

\section{Acknowledgement}

The authors wish to thank the Malaysia National Anti-Drug Agency (NADA) for funding this study (AADK Geran Ilmiah (100-IRMI/GOV 16/6/2 (011/2017)). The authors would also like to thank Universiti Teknologi MARA Selangor and Jabatan Ukur dan Pemetaan Malaysia (JUPEM) for providing the data. 
GEOGRAFIA Online ${ }^{\mathrm{TM}}$ Malaysian Journal of Society and Space 16 issue 3 (263-278)

(C) 2020, e-ISSN 2682-7727 https://doi.org/10.17576/geo-2020-1603-19

\section{References}

Astro Awani. (2019). Ketagihan dadah, jika tidak dibendung, negara kerugian tenaga belia. Retrieved from http://www.astroawani.com/berita-malaysia/ketagihan-dadah-jika-tidakdibendung-negara-kerugian-tenaga-belia-muhyiddin-206498.

Bernama. (2019). AADK sasar 33 kawasan bebas dadah menjelang akhir tahun ini. Retrieved from http://www.bernama.com/bm/news.php?id=1699854.

Berita Harian. (2018). Pahang, Kelantan, Terengganu, Perlis paling ramai penagih dadah. Retrieved from https://www.bharian.com.my/berita/nasional/2018/11/497259/pahangkelantan-terengganu-perlis-paling-ramai-penagih-dadah.

Brantingham, P.J., \& Brantingham, P.L. (1984). Patterns in crime. New York: Macmillan.

Boba, R.S. (2016). Crime Analysis with Crime Mapping, 4th Ed. Sage Publications, Inc, Thousand.

Oaks, California.

Chainey, S., \& Ratcliffe, J. (2005). GIS and crime mapping. Mastering GIS: Technology, Applications and Management. John Wiley \& Sons. England.

Chainey, S.P., Reid, S., \& Stuart, N. (2002). When is a hotspot a hotspot? A procedure for creating statistically robust hotspot maps of crime. Innovations in GIS 9. London: Taylor \& Francis.

Chainey, S. (2013). Examining the influence of cell size and bandwidth size on kernel density estimation crime hotspot maps for predicting spatial patterns of crime. Bull. Geogr. Soc. Liege, 60: 7-19.

Chan Y.F, Nor Aizam A. (2018). Using Geographical Information System to Identify High-Risk Areas of Substance Abuse in Malaysia. Jurnal Antidadah Malaysia.

Eck, J., Chainey, S.P., Cameron, J., \& Wilson, R. (2005). Mapping crime: Understanding hotspots. Washington DC: National Institute of Justice.

Esri. (2019). How kernel density works.

Retrieved from https://pro.arcgis.com/en/pro-app/tool-reference/spatial-analyst/howkernel-density-works.htm.

Fazillah, A., Juahir, H., Toriman, E., Mohamad, N., \& Mohamad, M. (2017). Combating substance abuse with the potential of geographic information system combining multivariate analysis. J. Fundam. Appl.Sci. 9(2S), 485-504.

Gill, C. Vitter, Z. \& Weisburd, D. (2015). Identifying Hot Spots of Juvenile Offending: A Guide for Crime Analysts. Retrieved from https://ric-zai-inc.com/Publications/cops-p298-pub.pdf

Gorr, W. L., \& Kurtland, K. S. (2012). GIS tutorial for crime analysis. Esri Press. Redlands. California. USA.

Jefferis, E. (1999). A multi-method exploration of crime hot-spots: A summary of findings. Crime Mapping Research Centre intramural project. Washington, DC: National Institute of Justice.

Kalinic, M., \& Krisp, J. (2018). Kernel Density Estimation (KDE) vs. Hot-Spot Analysis Detecting Criminal Hot Spots in the City of San Francisco. Conference: Agile 2018 - 21st Conference on Geo-information Science, At Lund, Sweden. Retrieved from https://www.researchgate.net/publication/325825793_Kernel_Density_Estimation_KDE_v s_Hot-Spot_Analysis__Detecting_Criminal_Hot_Spots_in_the_City_of_San_Francisco.

Leigh, J.M. Dunnett, S.J. \& Jackson, L.M. (2016). Predictive policing using hotspot analysis. Int. Multi-Conf. Eng. Comput. Sci. (IMECS 2016), 16-18 March 2016, Hong Kong. 
Malaysia. (2012). Drug Dependants (Treatment and Rehabilitation) Act 1983 (Act 283).

Malaysia. Anti Narcotics Task Force. (1992). Dadah (illicit drugs) : what you need to know / Anti Narcotics Task Force. National Security Council. Prime Minister's Department. Kuala Lumpur : Delmu (Malaysia).

NADA. (2017). Maklumat Dadah 2017. Retrieved from https://www.adk.gov.my/wpcontent/uploads/Terkini-Maklumat-Dadah-2017.pdf.

Silverman, B.W. (1986). Density estimation for statistics and data analysis. London: Chapman and Hall.

Tarmiji, M., \& Usman, Y. (2012). Population and spatial distribution of urbanisation in Peninsular Malaysia 1957-2000. Geografia-Malaysian Journal of Society and Space, 8(2), 20-29.

Toriman, M. E., Abdullah, S. N. F., Azizan, I. A., Kamarudin, M. K. A., Umar, R., \& Mohamad, N. (2015). Penilaian ruang dan masa terhadap penagihan dadah menggunakan analisis multivariat dan GIS. Malaysian Journal of Analytical Sciences, 19(6), 1361-1373.

United Nation. (2018). Bulletin on Narcotics. Alternative development: practices and reflections. Vol. LXI, 2017. 75-130. Office on Drugs and Crime (UNODC). Vienna International Centre. Austria.

United Nation. (2007). Types of Drugs under International Control. Office on Drugs and Crime (UNODC). Retrieved from https://www.unodc.org/pdf/typesofdrugs/pdf.

Utusan Malaysia. (2017). Gejala dadah makin membimbangkan. Retrieved from https://www.utusan.com.my/berita/nasional/gejala-dadah-makin-membimbangkan1.493419. 